\title{
HBB Gene Mutation
}

National Cancer Institute

\section{Source}

National Cancer Institute. HBB Gene Mutation. NCI Thesaurus. Code C156900.

A change in the nucleotide sequence of the HBB gene. 